\title{
JEKK
}

Jurnal Epidemiologi Kesehatan Komunitas

4 (1), 2019, 35-44

\section{Faktor yang Berisiko Terhadap Hipertensi pada Pegawai di Wilayah Perimeter Pelabuhan (Studi di Kantor Kesehatan Pelabuhan Kelas II Semarang)}

\author{
Eka Oktaviarini ${ }^{*}$, Suharyo Hadisaputro ${ }^{* *}$, Shofa Chasani ${ }^{* * *}$, Ari Suwondo ${ }^{* *}$, Henry Setyawan ${ }^{* *}$ \\ ${ }^{*}$ Kesehatan Pelabuhan Kelas II Semarang, ${ }^{* *}$ Fakultas Kesehatan Masyarakat Undip, ${ }^{* * *}$ Fakultas \\ Kedokteran Undip
}

\begin{abstract}
Background: Hypertension is an increase in arterial blood pressure where systolic blood pressure is $\geq 140 \mathrm{mmHg}$ or diastolic blood pressure $\geq 90 \mathrm{mmHg}$. Hypertension is often called the silent killer because it does not cause symptoms so the treatment is often late. Occupational-related diseases one of which is hypertension. The type of work, work environment, lifestyle and individual characteristics can be a factor of hypertension.

Methods: An analytical observational study using a case control design with 76 samples consisting of 38 cases and 38 controls taken by consecutive sampling. The variables studied were age, gender, family history, type of work, years of work, workload, work schedule, sedentary behavior, coffee drinking habits and smoking habits. Data were analyzed by bivariate and multivariate with logistic regression method.

Results: Significant factors for hypertension were $\operatorname{sex}(\mathrm{p}=0,012$; OR adjusted 6,$582 ; 95 \%$ CI $1,522-28,456)$ and the work type ( $\mathrm{p}=0,020$; OR adjusted 5,248; 95\%CI 1,292-21,316) as risk factors, while sedentary behavior ( $\mathrm{p}=0,030$; OR adjusted 0,311 ; 95\% CI $0,108-0,895$ ) as a protective factor. The factors that are not significant at risk are age, family history, years of work, workload, work schedule, coffee drinking habits and smoking habits.

Conclusion: Male and structural work type are risk factors, while sedentary behavior $\geq 6$ hours/day is protective factor. Probability at risk of hypertension is $75 \%$.
\end{abstract}

Keywords: Hypertension; Office; Port; Risk factor

*Penulis korespondensi : $\underline{\text { sha008yaz@yahoo.com }}$ 


\section{Pendahuluan}

Hipertensi adalah suatu peningkatan tekanan darah arteri dimana tekanan darah sistol lebih atau sama dengan $140 \mathrm{mmHg}$ atau tekanan diastol lebih atau sama dengan $90 \mathrm{mmHg}$ atau keduanya. ${ }^{1}$ Hipertensi disebut sebagai the silent killer karena sering tidak menunjukkan gejala apapun selama sepuluh sampai duapuluh tahun dan biasanya baru diketahui apabila telah terjadi komplikasi pada organ target seperti jantung, ginjal, otak dan mata sehingga pengobatannya terlambat dan mengurangi harapan hidup karena kelemahan fungsi organ-organ tersebut yang berakibat kecacatan bahkan kematian. ${ }^{1-7}$ Selain itu, hipertensi akan menambah beban ekonomi yang secara tidak langsung juga akan mempengaruhi kesejahteran baik di tingkat rumah tangga, regional maupun nasional. ${ }^{8}$

Prevalensi nasional hipertensi pada penduduk umur 18 tahun ke atas di Indonesia sebesar $25,8 \%$ dan survei Riskesnas tahun 2016 mencatat peningkatan hipertensi menjadi 30,9\%. ${ }^{9,10}$ Profil kesehatan Provinsi Jawa Tengah tahun 2014-2016 menunjukkan hipertensi masih menempati proporsi terbesar dari seluruh penyakit tidak menular (PTM) yaitu sebesar 57,89\% (2014); 57,87\% (2015) dan $60 \%$ (2016). ${ }^{11}$ Proporsi hipertensi untuk area pelabuhan berdasarkan laporan kunjungan poliklinik KKP Kelas II Semarang tahun 2016 adalah 16,65\% dan mengalami peningkatan pada tahun 2017 menjadi $21,09 \% .^{12,13}$ Proporsi hipertensi berdasarkan hasil survei deteksi dini pegawai kantor di wilayah perimeter sebagai sasaran target adalah $33,68 \%$ yang lebih besar daripada kejadian hipertensi pada pegawai berdasarkan Riskesdas tahun 2013 yaitu sebesar 20,6\% dan prevalensi hipertensi pada pekerja di pelabuhan pada tahun 2011 yaitu 21,88\%. ${ }^{14-16}$
Salah satu penyakit yang berhubungan dengan pekerjaan bersifat multifaktorial dan seringkali terkait di tempat kerja adalah hipertensi. ${ }^{17}$ Seorang pegawai selain harus menyelesaikan tugas pokok dan fungsinya juga harus menyelesaikan tugas-tugas lain yang diberikan oleh atasannya sehingga keadaan ini menuntut energi, waktu dan pikiran. ${ }^{17-19}$ Jenis pekerjaan, lingkungan kerja, gaya hidup dan karakteristik individu pekerja atau pegawai dapat menjadi faktor hipertensi. ${ }^{17}$ Pegawai menghabiskan waktu kurang lebih delapan jam dalam lima hari kerja sehingga tidak memiliki kebiasaan olahraga secara teratur. $^{20}$ Riskesdas mencatat proporsi tertinggi perilaku sedentari pada pegawai adalah $42,2 \%$ yaitu selama 3-5,9 jam. Perilaku sedentari adalah perilaku yang tidak banyak melakukan gerakan dimana postur duduk dan berbaring adalah yang paling dominan dalam keseharian tetapi tidak termasuk waktu tidur. Perilaku ini berisiko terhadap salah satu terjadinya penyakit pembuluh darah, jantung dan mempengaruhi umur harapan hidup. ${ }^{9}$

Kementerian Kesehatan menyebutkan, job content, beban kerja, jadwal kerja dan lain-lain dapat menyebabkan reaksi stres yang konsekuensi jangka panjangnya adalah penyakit hipertensi. ${ }^{21}$ Stres dapat meningkatkan aktivitas saraf simpatis karena pembuluh darah yang menyempit sehingga dapat meningkatkan tekanan darah secara bertahap dan apabila berkepanjangan hal ini dapat mengakibatkan tekanan darah menjadi tinggi yang mengakibatkan peningkatan ketidakhadiran pegawai, rendahnya produktivitas kerja dan peningkatan angka kecelakaan kerja. ${ }^{23-36}$ 


\section{Metode}

Penelitian ini merupakan penelitian observasional analitik menggunakan desain case control. Populasi adalah pegawai yang berada di wilayah perimeter pelabuhan dan tercatat dalam survei deteksi dini PTM KKP Kelas II Semarang pada tahun 2017. Sampel adalah pegawai yang menderita hipertensi menurut JNCVII (sampel kasus) dan pegawai yang memiliki tekanan darah yang tergolong normal (sampel kontrol). Jumlah sampel adalah 76 antara lain 38 kasus dan 38 kontrol. Sampel diambil dengan teknik consecutive sampling. Kriteria inklusi sampel adalah IMT normal dan tidak sedang dalam penggunaan kontrasepsi hormonal untuk perempuan. Sedangkan kriteria eksklusi antara lain memiliki penyakit penyerta (diabetes, gagal ginjal dan stroke), alamat tidak jelas atau tidak dapat ditemui setelah 3 kali didatangi, perempuan yang sedang hamil, purna dari tugas atau meninggal. Data dianalisis secara bivariat dan multivariat dengan metode regresi logistik.

\section{Hasil Penelitian}

Hasil penelitian menunjukkan bahwa terdapat 3 variabel yang secara statistik berhubungan dengan hipertensi pada pegawai di wilayah perimeter pelabuhan yaitu variabel jenis kelamin, jenis pekerjaan dan perilaku sedentari. Berdasarkan hasil tersebut yang termasuk faktor risiko terhadap hipertensi pada pegawai di wilayah perimeter pelabuhan adalah jenis kelamin dan jenis pekerjaan. sedangkan perilaku sedentari termasuk faktor protektif $(\mathrm{CI}<1)$ yang disajikan pada Tabel 1.

Hasil analisis multivariat dengan regresi logistik berganda metode Enter ditampilkan dalam Tabel 2 yang menunjukkan bahwa dari 10 variabel terdapat 3 variabel yang terbukti berisiko terhadap kejadian hipertensi antara lain jenis kelamin, jenis pekerjaan dan perilaku sedentari. Berdasarkan analisis multivariat, model persamaan yang diperoleh adalah $y$ $=-1,263+(1,884 \mathrm{x}$ jenis kelamin laki-laki $)$ $+(1,658 \times$ jenis pekerjaan struktural $)+(-$ $1,168 \times$ perilaku sedentari $\geq 6 \mathrm{jam} / \mathrm{hari})$. Perhitungan probabilitas kejadian hipertensi pegawai yang diperoleh adalah 75\%. Hal ini berarti bahwa pegawai dengan jenis kelamin laki-laki, jenis pekerjaan struktural dan perilaku sedentari $\geq 6 \mathrm{jam} /$ hari memiliki probabilitas untuk mengalami hipertensi sebesar $75 \%$, sedangkan $25 \%$ dipengaruhi faktor lain. Probabilitas sumbangan faktor risiko masing-masing variabel terhadap kejadian hipertensi antara lain jenis kelamin lakilaki $65 \%$, pekerjaan struktural $60 \%$ dan perilaku sedentari $\geq 6$ jam/hari $8 \%$ yang disajikan pada Tabel 2.

Tabel 1. Hasil analisis bivariat faktor-faktor yang berisiko terhadap hipertensi pada pegawai di wilayah perimeter pelabuhan

\begin{tabular}{llccccc}
\hline No & Variabel & $\begin{array}{c}\text { Kasus } \\
(\%)\end{array}$ & $\begin{array}{c}\text { Kontrol } \\
(\%)\end{array}$ & $\begin{array}{c}\text { Nilai } \\
p\end{array}$ & $\begin{array}{c}\text { Nilai } \\
\text { OR }\end{array}$ & 95\% CI \\
\hline 1 & Umur & & & & & \\
& $<43$ tahun & 42,1 & 52,6 & 0,358 & 1,528 & $0,618-3,779$ \\
& $\geq 43$ tahun & 57,9 & 47,4 & & & \\
2 & Jenis kelamin & & & & & \\
& Perempuan & 7,9 & 39,5 & 0,001 & 7,609 & $1,979-29,251$ \\
& Laki-laki & 92,1 & 60,5 & & &
\end{tabular}


3 Riwayat hipertensi keluarga

Tidak ada

$\begin{array}{lllll}50,0 & 65,8 & 0,163 & 1,923 & 0,763-4,844 \\ 50,0 & 34,2 & & & \\ 76,3 & 78,9 & 0,783 & 1,164 & 0,395-3,429 \\ 23,7 & 21,1 & & & \end{array}$

5 Jenis pekerjaan

Fungsional

Struktural

$6 \quad$ Masa kerja

$<10$ tahun

$\geq 10$ tahun

7 Beban kerja

$<7 \mathrm{jam} /$ hari

$\begin{array}{lllll}65,8 & 89,5 & \mathbf{0 , 0 1 3} & 4,420 & 1,287-15,181 \\ 34,2 & 10,5 & & & \end{array}$

$\geq 7 \mathrm{jam} / \mathrm{hari}$

$\begin{array}{lllll}47,4 & 47,4 & 1,000 & 1,000 & 0,405-2,461 \\ 52,6 & 52,6\end{array} \quad$.

$39,5 \quad 36,8 \quad 0,813 \quad 0,894 \quad 0,354-2,258$

$8 \quad$ Jadwal kerja

$60,5 \quad 63,2$

5 hari

$\begin{array}{ll}71,1 & 84,2 \\ 28,9 & 15,8\end{array}$

0,169

2,173

$0,710-6,652$

6 hari

$28,9 \quad 15,8$

9 Perilaku sedentari

$<6 \mathrm{jam} /$ hari

$\begin{array}{lllll}65,8 & 34,2 & 0,006 & 0,270 & 0,105-0,698\end{array}$

$\geq 6 \mathrm{jam} /$ hari

$34,2 \quad 65,8$

10 Kebiasaan konsumsi kopi

Tidak

$65,8 \quad 68,4$

$0,807 \quad 1,127 \quad 0,432-2,935$

Ya

$34,2 \quad 31,6$

Tabel 2. Hasil akhir model uji analisis regresi logistik

\begin{tabular}{clcccc}
\hline No & Variabel & B & P & OR adj & 95\% CI \\
1. & Jenis kelamin laki-laki & 1,884 & 0,012 & 6,582 & $1,522-28,456$ \\
2. & Jenis pekerjaan struktural & 1,658 & 0,020 & 5,248 & $1,292-21,316$ \\
3. & Perilaku sedentari $\geq$ 6 jam/hari & $-1,168$ & 0,030 & 0,311 & $0,108-0,895$ \\
& Constant & $-1,263$ & & & \\
\hline
\end{tabular}

\section{Pembahasan}

Jenis kelamin termasuk dalam faktor risiko yang tidak dapat diubah. Hasil penelitian ini sejalan dengan penelitian Hashani dkk di Kosovo tahun 2014 yang menunjukkan bahwa laki-laki 1,4 kali lebih berisiko hipertensi daripada perempuan. ${ }^{27}$ Teori juga menyebutkan bahwa laki-laki memiliki risiko lebih besar untuk menderita hipertensi daripada perem- puan. ${ }^{28}$ Aktivitas plasma renin (kadar prorenin dan renin) laki-laki biasanya lebih tinggi daripada perempuan yang akan berpengaruh pada sintesis AT II dalam sistem renin angiotensin. ${ }^{29}$ testosteron dapat secara langsung merangsang reabsorpsi natrium melalui tubulus proksimal ginjal. Androgen reseptor terlokalisir ke tubulus proksimal ginjal dapat mempengaruhi sintesis komponen Renin Angiotensin System (RAS) sehingga menyebabkan 
peningkatan produksi AT II di ginjal dan dengan demikian mempengaruhi tekanan darah. Salah satu mekanisme yang bisa digunakan adalah melalui efeknya pada produksi vasokonstriktor. ${ }^{30,31}$

Jenis pekerjaan struktural dalam penelitian ini terbukti sebagai faktor risiko. Hal ini sejalan dengan penelitian Yang dkk yang menyebutkan jenis pekerjaan administrasi serta pekerjaan lain yang tidak membutuhkan banyak keterampilan lebih berisiko. ${ }^{32}$ Hipertensi dapat menimpa pegawai dengan segala profesi dan jenis pekerjaan dengan kondisi lingkungan apabila tuntutan pekerjaan tidak sesuai dengan kemampuan atau kebutuhan pekerja misalnya, peralatan yang tidak memadai, hubungan yang buruk dengan atasan, konflik pribadi. ${ }^{20}$ Apabila hal ini berlangsung lama maka tubuh akan berusaha mengadakan penyesuaian sehingga timbul kelainan organis atau perubahan patologis dengan gejala yang muncul adalah hipertensi. ${ }^{22}$

Salah satu faktor gaya hidup atau perilaku sedentari adalah pekerjaan tertentu yang membuat orang selalu duduk di depan komputer, contohnya pegawai kantor. ${ }^{33}$ Perilaku sedentari adalah kebiasaan seseorang yang tidak banyak melakukan gerakan di mana postur duduk dan berbaring adalah yang paling dominan dalam keseharian seperti kerja di depan komputer, membaca, menonton televisi, bermain game dan lain-lain tapi tidak termasuk waktu tidur. ${ }^{9,31,34}$ Otot seseorang yang kurang melakukan aktivitas fisik cenderung akan mengendor sehingga peredaran darah akan terhambat dan kerja jantung akan lebih berat. memiliki curah jantung yang lebih tinggi sehingga semakin besar pula oksigen yang dibutuhkan oleh sel-sel tubuh. ${ }^{35}$ Bukti ilmiah dari berbagai sumber menunjukkan hubungan positif antara perilaku menetap dan kejadian hipertensi. Studi epidemiologi menilai hubungan antara perilaku sedentari dan tekanan darah dengan hasil yang tidak konsisten. Perilaku sedentari interaktif (penggunaan komputer dan mengemudi) tampaknya menjadi faktor risiko independen untuk kejadian hipertensi. Perilaku sedentari non-aktif (menonton televisi) tidak menunjukkan hubungan yang signifikan dengan kejadian hipertensi. 36

Tugas yang melibatkan interaksi (respon terhadap rangsangan eksternal) dan yang melibatkan elaborasi kognitif (aritmatika mental, memori, dan menghitung tugas) berhubungan dengan penurunan sensitivitas refleks baroreseptor. Perubahan pada pola pernapasan juga dapat memodifikasi sensitivitas refleks baroreseptor. Stres mental dapat menyebabkan otot perut berkontraksi dan pernapasan toraks (dengan pernapasan dangkal dan tingkat yang lebih cepat). Dalam jangka panjang, kondisi ini dapat mempengaruhi keseimbangan saraf otonom dan akhirnya meningkatkan tekanan darah. Mekanisme yang terlibat bisa dihubungkan dengan sekresi adrenalin oleh kelenjar adrenalin atau bahkan sekresi renin, yang juga terhubung ke sistem pengaturan neurologis tekanan darah. ${ }^{36}$

Faktor risiko yang tidak terbukti terhadap hipertensi antara lain umur, riwayat hipertensi keluarga, masa kerja, beban kerja, jadwal kerja, kebiasaan konsumsi kopi, dan kebiasaan merokok. Hal ini bertolak belakang dengan teori dan hasil penelitian lain yang menyatakan dengan bertambahnya usia, tekanan darah seseorang menjadi meningkat dimana umur $>42$ tahun merupakan faktor dominan yang berpengaruh terhadap hipertensi. ${ }^{16,33} \mathrm{Hal}$ ini dikarenakan adanya perubahan hormonal, keadaan stres, kelelahan, dan pola konsumsi makan yang tidak terkontrol. $^{37}$

Riwayat keluarga tidak terbukti sebagai faktor risiko padahal jelas disebutkan bahwa tekanan darah adalah 
sifat yang diwariskan dimana sekitar 30\% perbedaan tekanan darah berhubungan dengan faktor genetik. ${ }^{24}$ Hasil penelitian lain menunjukkan riwayat keluarga atau genetik sebesar 70-80\% kasus hipertensi merupakan kasus turunan dari orang tuanya. $^{38}$ Tekanan darah tercipta dari interaksi antar gen dan pengaruh dari lingkungan. Penemuan sejauh ini hanya menjelaskan $3 \%$ dari heritabilitas tekanan darah. $^{24}$

Masa kerja tidak terbukti berisiko terhadap hipertensi sejalan dengan penelitian Harianto tahun 2011 yang menyatakan bahwa masa kerja 6-12 tahun dan masa kerja > 12 tahun tidak memiliki hubungan yang signifikan dengan kejadian hipertensi. ${ }^{16}$ Masa kerja $\geq 10$ tahun yang diduga merupakan faktor risiko hipertensi dalam penelitian ini memiliki persentase yang sama pada kelompok kasus dan kelompok kontrol.

Beban kerja $\geq 7$ jam/hari pada kelompok kasus memiliki persentase yang lebih kecil daripada kelompok kontrol dan tidak terbukti sebagai faktor risiko. Hasil penelitian ini tidak sejalan dengan penelitian yang menunjukkan bahwa beban kerja yang terlalu tinggi secara signifikan berhubungan dengan hipertensi. ${ }^{39}$ Beban kerja dipengaruhi oleh 3 faktor utama antara lain uraian pekerjaan, waktu kerja dan jumlah tenaga. ${ }^{40}$ Dalam penelitian ini tidak dilakukan pengukuran terhadap produktivitas kerja dan 2 faktor utama yang mempengaruhi beban kerja yaitu uraian pekerjaan dan jumlah tenaga.

Jadwal kerja tidak berisiko terhadap hipertensi pada pegawai dimungkinkan hipertensi bukan disebabkan oleh faktor kelelahan fisik dalam bekerja karena jadwal kerja yang menjadi dasar dalam penelitian ini sesuai dengan peraturan kepegawaian yang berlaku dan beban kerja yang dirasakan oleh responden juga cenderung kecil untuk berisiko hipertensi. Penelitian ini sejalan dengan hasil penelitian di Ghana tahun 2014 yang menyatakan bahwa tidak ada hubungan yang signifikan antara jadwal kerja dan hipertensi pada pegawai. ${ }^{41}$

Kebiasaan konsumsi kopi tidak berisiko terhadap kejadian hipertensi sejalan dengan penelitian Enggarwati tahun 2014. ${ }^{42}$ Menurut Bealaer, konsumsi kafein dan tingkat asupan kafein tidak berkontribusi terhadap tekanan darah tinggi sebab efek tersebut akan menghilang dalam 5 hari. Berkaitan dengan waktu paruh kafein yang berkisar 4-5 jam maka efek kafein dalam tubuh akan menghilang setelah periode waktu paruh tersebut. ${ }^{43}$

Kebiasaan merokok tidak terbukti berisiko terhadap hipertensi sejalan dengan penelitian yang dilakukan Stefhany pada tahun 2012. ${ }^{44}$ Hasil penelitian ini bertolak belakang dengan beberapa hasil penelitian dan teori yang menyebutkan bahwa nikotin dalam rokok dapat menyebabkan terjadinya pengapuran pada dinding pembuluh darah sehingga merokok sebanyak 2 batang saja akan meningkatkan tekanan sisitolik maupun diastolik sebesar 10 $\mathrm{mmHg}$ dan kadar cotinine serum lebih tinggi pada perokok berisiko 3 kali lebih besar terhadap tekanan darah sistolik. ${ }^{45-47}$ Hasil penelitian ini berbeda dikarenakan proporsi responden yang tidak memiliki kebiasaan merokok lebih besar daripada yang memiliki kebiasaan merokok.

\section{Kesimpulan}

Faktor yang terbukti sebagai faktor risiko hipertensi pada pegawai di perimeter pelabuhan adalah jenis kelamin laki-laki dan jenis pekerjaan struktural, sedangkan perilaku sedentari $\geq 6 \mathrm{jam} /$ hari merupakan faktor protektif. Faktor-faktor tersebut memiliki probabilitas $75 \%$ terhadap kejadian hipertensi. Faktor yang tidak terbukti berisiko adalah umur, riwayat hipertensi di keluarga, masa kerja, beban kerja, jadwal kerja, kebiasaan konsumsi 
kopi, dan kebiasaan merokok.

\section{Ucapan Terimakasih}

Terimakasih kepada pada pegawai di perimeter pelabuhan yang bersedia menjadi obyek penelitian dan memberikan kontri-busi dalam pengumpulan data.

\section{Daftar Pustaka}

1. WHO-ISH. 2003. Hypertension Guideline Committee. Guidelines of the management of hypertension. $\mathbf{J}$ Hypertension;21(11).pp.1983-1992.

2. Hartono B. 2017. Hipertensi: The Silent Killer. Perhimpunan Hipertensi Indonesia. [Cited 2017 October 24]. Available from http://www.inash. or.id/upload/news_pdf/news_DR_Drs _Bambang_Hartono_SE26.pdf.

3. Siauw S I.1994.Tekanan Darah Tinggi atau Hipertensi. Solo: PT. Dabara Bengawan.

4. Guyton AC, Hall JE. 2007. Buku Ajar Fisiologi Kedokteran (Terjemahan). 11 ed. Irawati, Ramadani D, Indriyani F . Jakarta: Penerbit Buku Kedokteran EGC.pp.423-435.

5. WHO/SEARO. 2011. Non Communicable Diseases: An Information Booklet. WHO : Department of Communicable Disease; 2011.p.1720. [Cited 2018 April 24]. Available from:http://apps.who.int/iris/bitstream/ handle/10665/205579/B4980.pdf?sequ ence $=1 \& u a=1$.

6. CDC.2002. State-specific trend in self report 3rd blood pressure screening and high blood pressure-United States 1991-1999. MMWR;51(21). pp.456.

7. Joint National Committee on Prevention, Detection, Evaluation, and Treatment of High Blood Pressure (JNC). 2003. The Seventh Report of the JNC (JNC-7). JAMA;289 (19).pp. 2560-2572.

8. Kementerian Kesehatan Republik Indonesia. 2018. Sebagian besar penderita hipertensi tidak menyadarinya. Jakarta: Biro Komunikasi dan Pelayanan Masyarakat Sekretariat Jenderal Kementerian Kesehatan RI; 2017 [cited 2018 April 5]. Available from http://www.depkes.go.id/ article/ print/17051800002/sebagian-besarpenderita-hipertensi-tidakmenyadarinya.html.

9. Rahajeng E, Tuminah S. 2009. Prevalensi hipertensi dan determinannya di Indonesia. Majalah Kedokteran Indonesia;59(12).

10. Sekretariat Jenderal Kementerian Kesehatan RI. 2017. Profil Kesehatan Indonesia Tahun 2016. Jakarta: Kementerian Kesehatan RI; 2017. [cited 2018 April 5]. Available from http://www.depkes.go.id/resources/do wnload/pusdatin/profil-kesehatanindonesia/Profil-Kesehatan-Indonesia2016.pdf

11. Profil Kesehatan Provinsi Jawa Tengah Tahun 2016 [Cited 2018 April 8]. Available from http://dinkesjatengprov.go.id/v2015/dokumen/profil2016 /mobile/index.html

12. KKP Semarang. 2017. Profil Kantor Kesehatan Pelabuhan Kelas II Semarang Tahun 2016. Semarang: KKP Semarang.

13. KKP Semarang. 2018. Profil Kantor Kesehatan Pelabuhan Kelas II Semarang Tahun 2017. Semarang: KKP Semarang.

14. KKP Semarang. 2017. Laporan Survei Deteksi Dini Penyakit Tidak Menular. Semarang.

15. Badan Penelitian dan Pengembangan Kesehatan Depkes RI. 2013. Riset Kesehatan Dasar (RISKESDAS) 2013. Jakarta: Balitbangkes. 
16. Harianto E, Pratomo H. 2013. Pajanan Kebisingan dan Hipertensi di Kalangan Pekerja Pelabuhan. Jurnal Kesehatan Masyarakat Nasional;8 (5). pp.215-220. http://journal.fkm.ui.ac. $\mathrm{id} /$ kesmas/article/view/387

17. Jeyaratman and Koh. 2010. Alih bahasa: Suryadi. Buku Ajar Praktik Kedokteran Kerja. Jakarta: EGC.

18. Tsutsumi A, Kayaba K, Tsutsumi K, Igarashi M, and Jichi Medical School Cohort Study Group.2001. Association Between Job Strain and Prevalence of Hypertension : A Cross Sectional Analysis in A Japanese Working Population with A Wide Range of Occupations. The Jichi Medical School Cohort Study. Occup Environ Med.pp.58.

19. Rosenthal T, Alter A. 2011. Occupational Stress and Hypertension. Journal of The American Society of Hypertension:6(1).

20. Price SA.2006. Patofisiologi: Konsep Klinis Proses-Proses Penyakit. Edisi 6. Jakarta: EGC.

21. Koenig HG, Vandermeer J, Chambers A, Burr-Crutchfield L, Johnson J. 2006. Minor depression physical outcome trajectories in heart failure and pulmonary disease. Journal of Nervous and Mental Disease; 194(3).pp.209-217.

22. Yogiantoro M. 2006. Hipertensi Essensial. In: Sudoyo AW, Setyobudi $\mathrm{B}$, et al, editor. Buku Ajar Ilmu Penyakit Dalam Jilid I. Edisi IV. Jakarta: Pusat Penerbitan Ilmu Penyakit Dalam FK-UI.pp.599-603.

23. Dhania DR. 2012. Pengaruh stres kerja, beban kerja terhadap kepuasan kerja pada medical representatif di Kota Kudus. Jurnal Psikologi Universitas Muria Kudus;1(1).pp.1523.
24. Poulter N R, Prabhakaran D, Caulfield M. 2015. Hypertension. Lancet; 386.pp. 801-812.

25. Schneiderman $\mathrm{N}$, Ironson $\mathrm{G}$, and Siegel SD. 2005. Stress and health: psychological, behavioral, and biological determinants. Annual review of clinical psychology. 2005;1: 607-28.

26. Kemenkes. Gangguan Kesehatan Akibat Faktor Psikososial di Tempat Kerja. Jakarta: Biro Komunikasi dan Pelayanan Masyarakat Sekretariat Jenderal Kementerian Kesehatan RI; 2011.

27. Hashani V, Roshi E, Burazeri G. Correlates of hypertension among adult men and women in Kosovo. Materia socio-medica: 2014; 26(3) p.213-5. \{Cited 2017 October 23]. Available from :

http://www.pubmedcentral.nih.gov/arti clerender.fcgi $?$ artid $=4130693 \&$ tool $=p$ mcentrez\&rendertype $=$ abstract

28. Fisher NDL, Williams GH. Hypertensive Vascular Disease. Harrison's Principles of Internal Medicine. $16^{\text {th }}$ ed. New York: The McGraw-Hill Companies, Inc.; 2005. p.1463-1481.

29. Reckelhoff, JF. Sex Steroids, Cardiovascular Disease, and Hypertension Unanswered Questions and Some Speculations. Hypertension. 2005; 45: 170-174. [Cited 2018 November 13]. Available from https://www.ahajournals.org/doi/pdf/1 0.1161/01.HYP.0000151825.36598.36

30. Quan A, Chakravarty S, Chen J-K, Chen J-C, Loleh S, Saini N, Harris R, Capdevila J, Quigley R. Androgens augment proximal tubule transport. Am J Physiol Renal Physiol. 2004;287:F452-F459.

31. Sandberg K, Ji H. Sex differences in primary hypertension . Biology of Sex Differences. 2012; 3(7): 1-21. [Cited 
2018 November 13]. Available from https://bsd.biomedcentral.com/track/p df/10.1186/2042-6410-3-7

32. Fadila I. Relasi Perilaku Sedentari, Gizi Lebih dan Produktivitas Kerja Masyarakat Perkotaan. In: Toha M, Diki, Utami S, Dwisatyadini M, Kurniawati H, editor. Peran Matematika, Sains, dan Teknologi Dalam Mendukung Gaya Hidup Perkotaan (Urban Lifestyle) Yang Berkualitas. Tangerang Selatan : Universitas Terbuka; 2016. p.59-76. [Cited 2018 April 7]. Available at http://repository.ut.ac.id/7087/1/UTF MIPA2016-03-ila.pdf

33. Hardy, L. L., Booth, M. L., \& Okely, A. D. (2007). The Realibility of the Adolecent Sedentary Activity Questionnaire (ASAQ). Preventive Medicine , 45, 71-74.

34. Tremblay MS, Aubert S, Barnes JD, Saunders TJ, Valerie C, LatimerCheung AE, et al. Sedentary Behaviour Research Network (SBRN)Terminology Consensus Project Process and Outcome. Int J Behav Nutr Phys Act. 2017: 14 (75) [Cited 2018 April 18]. Available at:

https://www.ncbi.nlm.nih.gov/pmc/arti cles/PMC5466781/

35. Kristanti CM. Kondisi Fisik Kurang Gerak dan Instrumen Pengukuran. Artikel. Media Litbang Kesehatan. 2002; XII (1): 1-5. [Cited 2018 April 9] Available from http://repository.litbang.kemkes.go.id/1 129/

36. Beunza JJ, Martı'nez-González MA, Ebrahim S, et al. Sedentary Behaviors and the Risk of Incident Hypertension. Am J Hypertens. 2007;20:1156-62. [Cited 2018 November 13]. Available from

https://pdfs.semanticscholar.org/55b3/f 732e7d4b522ae24854e79f24eabe8b42e ec.pdf
37. Pate RR. Physical Activity and Public Health - A Recommendation from the Centers for Disease Control and Prevention and the American College of Sports Medicine.[Cited 2018 April 7]. Available at : http://wonder.cdc. gov/wonder/prevguid/p0000391/p0000 391.asp

38. Sundari S, Aulaniam A, Wahono. 2013. Faktor Risiko Non Genetik dan Polimorfisme Promoter RegionGen CYP11B2 Varian T(-344)C Aldosterone Synthasepada Pasien Hipertensi Esensial di Wilayah Pantai dan Pegunungan. Jurnal Kedokteran Brawijaya: 27(3).pp.169-177. [Cited 2017 October 23]. Available from : http://jkb.ub. ac.id/index.php/jkb/article/view/345

39. Ducher M, Cerutti C, Chatellier G, Fauvel JP. 2006. Is High Job Strain Associated With Hypertension Genesis ?. American Journal of Hypertension; 19(7).pp.694-700. [Online]. [Cited 2018 July 27]. Available from https://www.ncbi.nlm.nih.gov/pubmed/ 16814123

40. Aldes D. 2017. Analisis Beban Kerja. Padang: Biro Organisasi Provinsi Sumatra Barat.[Cited 2018 April 21]. Available from https://www.sumbarprov.go.id/images/2017/10/file/analisis beban_kerja.pdf

41. Daitey PEM. 2014. Assesment of Work Related Hypertension among Bank Workers in Accra.[Abstrak]. Cited 2018 July 29. Available from http://ugspace.ug.edu.gh/handle/12345 $6789 / 7395$

42. Enggarwati P, Dahlia D. 2014. Tekanan Darah Berdasarkan Pola Konsumsi Kopi Civitas Akademika Fakultas Ilmu Keperawatan Universitas Indonesia. Depok: FIK UI. [Cited 2017 Maret 25]. Available from http://lib.ui.ac.id/naskahringkas/201606/S56908-Pandan\%20Enggarwati 
43. Bealer BK, Weinberg BA. 2009. The Miracle of caffeine: Manfaat Tak Terduga Kafein Berdasarkan Penelitian Mutakhir. Bandung: Penerbit Qanita.

44. Stefhany E. 2012. Hubungan Pola Makan, Gaya Hiduo dan Indeks Massa Tubuh dengan Hipertensi pada Pra Lansia dan Lansia di Posbindu Kelurahan Depok Jaya Tahun 2012. Jakarta: FKM Universitas Indonesia. [Cited 2018 July 27]. Available from http://lib.ui.ac.id/file?file=digital/20319 769-S-PDF-

Emerita\%20\%20Stefhany.pdf.
45. Bustan MN. 2007. Epidemiologi Penyakit Tidak Menular. Jakarta: Rineka Cipta.

46. Alshaarawy O, Xiao J, Shankar A.2013. Association of Serum Citinine Levels and Hypertension in Never Smokers. Hypertension: 61(2).pp.3048. [Cited 2017 October 23]. Available from http://www.ncbi.nlm. nih.gov/ pubmed/23184382

47. Dalimartha S. Purnama BT, Sutarina N, Mahendra B, Darmawan R. 2008. Care yourself, hipertensi. Jakarta : Penebar Plus. 